\title{
group species
}

\section{medium length}

\section{exons \\ introns}

human

chimp

mouse

rat

dog

cow

chicken

frog

zebrafish

honeybee

fruitfly

worm
134

128

134

125

121

120

126

121

118

125

274

157
1,525

1,504

1,250

1,085

1,006

969

816

855

704

159

82

67 